\title{
PENINGKATAN KEMAMPUAN MENULIS PARAGRAF DALAM MENEMUKAN IDE POKOK DENGAN MENERAPKAN METODE INKUIRI SISWA KELAS IV SDN 2 LAEMANTA
}

\author{
Suparni \\ Program Studi Bahasa dan Sastra Indonesia, Fakultas Sastra, Universitas Alkhairaat \\ Suparniani380@gmail.com
}

\begin{abstract}
ABSTRAK
Penelitian ini bertujuan untuk mendeskripsikan penerapan metode inquiri untuk meningkatkan kemampuan menulis paragraf kelas IV SD Negeri 2 Laemanta. Dalam penelitian dilakukan dua siklus, yaitu siklus I dan siklus II dengan target nilai rata-rata minimal 75. Desain penelitian model Kemmis dan Mc. Tagart, penelitian dilakukan melalui proses perencanaan, tindakan, observasi, dan refleksi. Dari hasil peningkatan menulis paragraf dengan menerapkan metode inkuiri siklus I diketahui bahwa jumlah rata-rata kelas 66,50 dan ketuntasan 30\% yang masuk kategori cukup baik, Sementara itu, nilai rata rata pada siklus II sebesar $84 \%$ dan ketuntasan $85 \%$ yang termasuk dalam kategori sangat baik. Maka dengan itu, hasil yang diperoleh tersebut telah memenuhi kriteria ketuntasan klasikal sebagaman yang ditetapkan pada indikator penelitian minimal $75 \%$.
\end{abstract}

Kata kunci: Menulis, Paragraf, Metode Inkuiri.

\begin{abstract}
This study aims to describe the application of inquiry methods to improve the ability to write paragraphs of class IV of Laemanta Elementary School 2. In the study carried out two cycles, namely cycle I and cycle II with a target of a minimum average value of 75. The research design model is Kemmis and MC. Tagart, research is carried out through a process of planning, action, observation, and reflection. From the results of the increase in writing paragraphs using the Cycle I inquiry method it is known that the number of class averages of 66.50 and completeness of $30 \%$ which are categorized quite good, meanwhile, the average value in cycle II is $84 \%$ and completeness $85 \%$ is included in very good category. So with that, the results obtained have met the classical completeness criteria as specified in the research indicators of at least $75 \%$.
\end{abstract}

Keywords: Writing, Paragraph, Inquiry methods.

\section{PENDAHULUAN}

Menulis adalah keterampilan berbahasa dengan mengepresikan pikiran dan perasaan yang disampaikan melalui bahasa tulis, pikiran yang disampaikan kepada orang lain harus dinyatakan dengan kata kata yang mendukung makna secara tepat dan sesuai dengan apa yang ingin sampaikan dalam tulisan. Menulis dapat dikatakan suatu proses berpikir dan menuangkan pikiran dalam bentuk karangan. Menulis sangat penting bagi pendidikan karna menulis memudahkan para pelajar berpikir. Selain itu, menulis memudahkan seseorng merasakan dan menikmati hubungan hubungan memperdalam daya tanggap atau persepsi seseorng dan juga menusun urutan bagi pengalaman. Dengan demikian, menulis 
melatih untuk mengepresikan berbagai pikiran, gagasan, pendapat dan perasaan dalam bentuk lambang bahasa tulis.

Salah satu jenis menulis adalah keterampilan menulis paragraf, paragraf merupakan kalimat yang saling berkaitan antara satu kalimat dengan kalimat lain. Paragraf juga disebut sebagai karangan yang singkat. Paragraf membantu memecah teks panjang sehingga lebih mudah dicernah oleh pembaca.

Berdasarkan hasil pengamatan peneliti pada pelaksanaan pratindakan dari hasil observasi dan wawancara terhadap guru dan siswa kelas IV SDN II Laemanta diketahui kemampuan menulis paragraf untuk menemukan pendapat atau ide pokok gagasan masih rendah. Penyebabnya, siswa kurang berlatih menulis karangan. Selain itu, siswa SDN II Laemanta belum menguasi teknik dalam menemukan masalah utama dengan tepat. Dari hasil kemampuan siswa kelas IV SDN II Laemanta masih sangat rendah. Hal ini, dilihat dari nilai rata-rata yang hanya mencapai $65 \%$ dan berada dibawah kriteria ketuntasan minimal (KKM) dari angka 70\%. Untuk itu, perlu dilakukan penelitian tindak kelas.

Dari hasil pengamatan peneliti terhadap keterampilan menulis di kelas IV SDN II Laemanta belum optimal karena siswa kesulitan dalam menyusun paragraf dan menentukan ide pokok gagasan. Faktor penghabatnya adalah (1) siswa belum mampu dalam menuangkan gagasan, (2)siswa kesulitan dalam penggunaaan kata yang tepat, (3) penyusunan paragraf kurang maksimal, (4) penggunaan kaidah ejaan kurang benar, (5) penguasaan kosa kata kurang memadai.

Sehubungan degan itu, permasalahan yang diajuakn adalah bagaimanakah peningkatan kemampuan menulis paragraf dengan menerapkan metode inkuiri siswa SDN II Laemanta? Dan bagamankah penerapan metode inkuiri dalam keterampilan menulis paragraf siswa SDN II Laemanta? Seiring dengan ini, bertujuan untuk mengetahui peningkatan kemampuan menulis paragraph dengan menerapkan metode inkuiri siswa SDN II Laemanta dan bertujuan untuk mendeskripsikan penerapan metode inquiri siswa SDN II Laemanta.
Salah satu alternatif untuk mengatasi masalah tersebut peneliti menyarankan agar guru menerapkan metode inkuri agar siswa dapat mengikuti proses pembelajaran yang terarah dan menyenangkan, dengan diterapkan metode inkuiri siswa diharapkan dapat memahami tentang menulis paragraf dengan baik karena metode inkuiri ini sangat sederhana dan membantu para siswa untuk mengepresikan berbagai pikiran, gagasan, pendapat dan perasaan.

Prinsip prinsip inkuiri menurut Sanjaya (2011:196) 'model pembelajaran inkuiri adalah rangkaian kegiatan pembelajaran yang menekankan pada proses berpikir secara kritis dan analitis untuk mencari dan menemukan sendiri jawaban suatu masalah yang dipertanyakan" Metode inkuiri memberikan kebebasan kepada siswa untuk berpikir kritis dan analisis mencari masalah yang dipelajarinya. Sejalan dengan itu, Hanafiah dan Suhana (2010) menjelaskan bahwa metode inkuiri merupakan suatu rangkaian kegiatan pembelajaran yang melibatkan secara maksimal seluruh kemampuan siswa untuk mencari dan menemukan secara sistematis, kritis dan logis sehingga dapat menemukan sendiri pengetahuannya.

Dengan demikian, menurut beberapa pendapat di atas bahwa metode inkuiri adalah pembelajaran yang melibatkan siswa berperan aktif dalam mencari, menemukan, masalah yang dilakukan dengan cara observasi bertanya ivestigasi, amnalisis kemudian membangun konsep dengan menyimpulkan hasil pembelajaran dan siswa dituntut berperan aktif dalan kegiatan pembelajaran sehingga dapat merumuskan temuannya.

Paragraf adalah bagian dari suatu karangan yang terdiri atas jumlah kalimat yang mengungkapkan satuan informasi dengan ide pokok sebagai pengendalinya, menurut Ramlan (dalam Rohmadi dan Nasucha, 2010) "sebuah paragraph selalu memeliki ide pokok yang merupakan inti dari informasi yang diungkapkan dalam paragraf. Sehubungan dengan itu akhaidiah (dalam Rohmadi dkk, 2009) "paragraf merupakan inti yang terkandung satu unit buah pikiran yang didukung oleh semua kalimat dalam paragraf tersebut, mulai dari kaliamt 
pengenal, kaliamt utama, kalimat penjelas sampai kaliamt penutup. Paragraf juga dikatakan kaliamt sangat pendek. Menurut Wiyanto (2014) paragraf adalah sekelompok kalimat yang saling berhubungan dan bersama sama menjelaskan satu unit pokok pikiran.

Dari beberapa pendapat di atas, dapat disimpulkan bahwa paragraf adalah seperangkat kaliamt tersusun secara logis sistematis yang merupakan bagian integral dari ide pokok yang terkandung dalam keseluruhan karangan.

Oleh karena itu, pembelajaran menulis memiliki kedudukan yang tinggi disbanding keterampilan Bahasa lainnya, keterampilan memiliki empat aspek yaitu menyimak berbicara, membaca, dan menulis. Menurut Tarigan (20083) menulis merupakan suatu keterampilan Bahasa yang dipergunakan untuk berkomunikasi secara tidak langsung. Tarigan juaga menegaskan (2008) menulis adalah melukiskan lambing lambing grafik yang menggambarkan suatu bahasa yang dipahami oleh seseorang

Dengan demikian, menulis adalah salah satu cara manusia dalam berkomunikasi selain mendengar, membaca, dan berbicara, sehingga pesan yang disampaikan bias berupa informasi, gagasan, pikiran, dan sebagainya.

\section{METODE PENELITIAN}

Penelitian ini menggunakan penelitan tindakan kelas. Latar penelitian ini adalah SD Negeri 2 Laemanta yang berjumlah 20 orang terdiri dari 12 orang perempuan dan 8 orang laki-laki. Desain penelitian ini menggunakan model siklus Kemmis dan MC. Tagart model spiral, penelitian tindak kelas ini dilakukan melalui proses perencanaan, tindakan, observasi, dan refleksi (Rochiati, 2012). Pengumpulan data pada siklus I dan II menggunakan teknik tes dan non tes. Teknik tes digunakan untuk mengetahui tingkat menulis paragraf dengan menerapkan metode inkuiri, teknik nontes digunakan oleh peneliti untuk mengumpulkan data kualitatif berupa wawancara, observasi, catatan lapangan, dan dokumentasi. Teknik tes dianalis dengan data kuantitatif sementara teknik tes dianalisis dengan data kualitatif. Prosedur penelitian ini terdiri dari beberapa siklus yang masing masing siklus meliputi perencanaan, pelaksanaan tindakan, observasi dan refleksi. Prosedur pelaksanaan rancangan penelitian tindak kelas dapat dijabarkan sebagai berikut:

1. Pada tahap perencanaan, peneliti merencanakan kegiatan yang akan dilakukan pada penelitian tindak kelas (PTK). Kegiatan yang dilakukan pada perencanaan sebagai berikut: (a) menyusun rencana pembelajaran menulis paragraf untuk menemukan masalah utama dengan menerapkan metode inkuiri, (b) membuat dan menyiapkan instrument penelitian berupa lembar observasi dan, (c) menyusun rancangan yang meliputi tes.

2. Pada tahap pelaksanaan tindakan peneliti melaksanakan tindakan sebagai upaya perbaikan kemampuan menulis paragraf dengan menerapkan metode inkuiri siswakelas IV SDN 2 Laemanta, tindakan yang dilakuakan oleh peneliti pada setiap siklus sesuai dengan yang tersusun dalam RPP yaitu peneliti menyampaikan tentang tujuan dan manfaat pembelajaran menulis paragraph denagn menerapkan metode inkuiri dan siwa diberi motivasi untuk meningkatkan minat dalam pembelajaran menulis paragraf dengan metode inkuiri.

3. Pada tahap observasi, pengamatan peneliti tentang kegiatan siswa sela,ma penelitian berlangsung . observasi akan dilaksanakan peneliti tentang segala peristiwa aktivitas siswa selama proses pembelajaran maupun respon terhadap metode inkuiri, dalam proses observasi data diperoleh melalui beberapa cara yaitu: (a) observasi untuk mengetahui aktivitas guru dalam melakukan pembelajaran di kelas dan, (b) observasi siswa untuk mengetahui tingkah laku dan aktivitas siswa selama proses pembelajaran menulis berlangsung.

4. Refleksi merupakan bagian yang amat penting untuk memahami dan memberikan makna terhadap proses dan hasil (perubahan) yang menjadi akibat adanya tindakan yang dilakukan. Hasil refleksi digunakan untuk menerapkan langkah selanjutnya dalam upaya menghasilkan perbaikan pembelajaran 


\section{HASIL DAN PEMBAHASAN}

Sebelum penyajian data hasil tes pembelajaran menulis paragraf dalam menemukan ide pokok dengan menerapkan metode inkuiri pada siklus I dan II, peneliti menyajikan hasil pratindakan, hasil pratindakan merupakan data yang digunakan untuk mengetahui kemampuan siswa SD Negeri 2 Laemanta. Hasil pratindakan ini menjadi kondisi awal siswa sebelum mendapatkan mentode inkuiri, pada pembelajaran kemampuan menulis paragraf melalui metode inkuiri pada siklus I meruppakan tindakan penelitian dengan menerapkan metode inkuiri dan pada pembelajaran siklus II merupakan perbaikan dari pembelajaran siklus I dengan kekurangan kekurangan yang ada pada siklus I akan diperbaiki pada siklus II.

\section{Pratindakan}

Hasil pratindakan berupa keterangan menulis paragraf sebelum dilakukan penelitian. Pratindakan dimaksudkan untuk mengetahui kemampuan menulis paragraf dengan menentukan ide pokok. Hasil pratindakan perlu dianalisis untuk mengetahui kondidi awal kemampuan siswa menulis paragraf. Hal ini, dapat dilihat pada pratindakan belum mencapai $\mathrm{KKm}$. Nilai yang diperoleh siswa pada pembelajaran menulis paragraf untuk menemukan ide pokok dapat dilihat pada tabel berikut:

Tabel 1. Penilaian menulis Paragraf Pratindakan

\begin{tabular}{|c|c|c|c|c|c|c|c|}
\hline No & Nama & $\begin{array}{l}\text { A-1 } \\
20\end{array}$ & $\begin{array}{c}\text { A-2 } \\
30\end{array}$ & $\begin{array}{c}\text { A-3 } \\
\text { 30 }\end{array}$ & $\begin{array}{l}\text { A-4 } \\
20\end{array}$ & $\begin{array}{c}\text { Skor } \\
100\end{array}$ & Ketuntasan \\
\hline 1 & Siswa 1 & 15 & 15 & 15 & 15 & 60 & Tidak tuntas \\
\hline 2 & Siswa 2 & 15 & 10 & 10 & 15 & 50 & Tidak tuntas \\
\hline 3 & Siswa 3 & 15 & 10 & 10 & 15 & 50 & Tidak tuntas \\
\hline 4 & Siswa 4 & 10 & 10 & 10 & 10 & 40 & Tidak tuntas \\
\hline 5 & Siswa 5 & 10 & 10 & 5 & 10 & 35 & Tidak tuntas \\
\hline 6 & Siswa 6 & 15 & 15 & 15 & 15 & 60 & Tidak tuntas \\
\hline 7 & Siswa 7 & 10 & 15 & 15 & 10 & 50 & Tidak tuntas \\
\hline 8 & Siswa 8 & 15 & 10 & 10 & 15 & 60 & Tidak tuntas \\
\hline 9 & Siswa 9 & 10 & 10 & 10 & 10 & 40 & Tidak tuntas \\
\hline 10 & Siswa 10 & 15 & 15 & 10 & 15 & 55 & Tidak tuntas \\
\hline 11 & Siswa 11 & 15 & 20 & 15 & 15 & 55 & Tidak tuntas \\
\hline 12 & Siswa 12 & 15 & 20 & 15 & 15 & 65 & Tidak tuntas \\
\hline 13 & Siswa 13 & 15 & 20 & 15 & 15 & 60 & Tidak tuntas \\
\hline 14 & Siswa 14 & 15 & 15 & 15 & 15 & 60 & Tidak tuntas \\
\hline 15 & Siswa 15 & 15 & 20 & 15 & 15 & 65 & Tidak tuntas \\
\hline 16 & Siswa 16 & 15 & 15 & 15 & 15 & 60 & Tidak tuntas \\
\hline 17 & Siswa 17 & 15 & 20 & 15 & 10 & 60 & Tidak tuntas \\
\hline 18 & Siswa 18 & 15 & 15 & 10 & 15 & 55 & Tidak tuntas \\
\hline 19 & Siswa 19 & 15 & 15 & 15 & 15 & 60 & Tidak tuntas \\
\hline 20 & Siswa 20 & 15 & 10 & 10 & 15 & 50 & Tidak tuntas \\
\hline \multicolumn{2}{|c|}{ Jumlah } & 270 & 290 & 250 & 275 & 1095 & \\
\hline \multicolumn{2}{|c|}{ Ketercapaian } & $65 \%$ & $43 \%$ & $41,66 \%$ & $68 \%$ & $54,75 \%$ & $100 \%$ \\
\hline
\end{tabular}

Rumus:

Nilai $=\left(\frac{\text { skor perolehan }}{\text { skor maksimal }}\right) \quad x 100$

\author{
Keterangan analisis pencapaian indikator \\ A-1 = kesatuan gagasan dasar \\ A-2 = penggunaan struktur \\ $\mathrm{A}-3=$ pemilisan diksi \\ A-4 $=$ tanda baca dan ejaan
}

Data tabel pada menilaian menulis paragraf belum ada siswa yang memperoleh yang tuntas. Nilai yang diperoleh siswa belum mencapai nilai KKM. Adapun skor tertinggi yang dicapai oleh siswa 65 dan skor terendah 35 , jadi nilai rata rata kelas hanya mencapai $54,75 \%$. Dari hasil analisis kecepaian indicator, siswa menulis kesatuan dasar hanya mencapai 65\%, menulis 
penggunaan stuktur $43 \%$, pemilihan diksi $41,66 \%$, dan menulis tanda baca dan ejaan yaitu $68 \%$ untuk itu perlu dilaksanakan tindakan kelas sebab nilai rata rata kelas belum mencapai KKM.

Dari hasil pratindakan dapat diketahui bahwa hasil menulis paragraf siswa kelas IV SD Negeri 2 Laemanta masih berkategori sangat kurang. Skor rata rata keseluruhan belum mencapai skor maksimal.

\section{Tindakan Siklus I}

Data hasil observasi pengamat pada siklus I ini, untuk mengetahui kemampuan dan keberhasilan peneliti dalam melakukan kegiatan mengajar di kelas. Hasil penelitian ini diambil pada saat proses kegiatan mengajar berlangsung. Dari hasil tersebut, maka diperoleh nilai hasil observasi pengamat. Untuk itu, dapat dilihat pada tabel berikut ini.

Tabel 2. Penilaian Menulis Paragraf Siklus I

\begin{tabular}{ccccccccc}
\hline No & Nama & A-1 & $\begin{array}{c}\text { A-2 } \\
\text { 20 }\end{array}$ & $\begin{array}{c}\text { A-3 } \\
\mathbf{3 0}\end{array}$ & $\begin{array}{c}\text { A-4 } \\
\mathbf{2 0}\end{array}$ & $\begin{array}{c}\text { Skor } \\
\mathbf{1 0 0}\end{array}$ & Ketuntasan \\
\hline 1 & Siswa 1 & 20 & 20 & 20 & 20 & 80 & Tuntas & \\
2 & Siswa 2 & 15 & 15 & 15 & 15 & 60 & & Tidak tuntas \\
3 & Siswa 3 & 15 & 20 & 15 & 15 & 65 & & Tidak tuntas \\
4 & Siswa 4 & 20 & 20 & 20 & 15 & 75 & Tuntas & \\
5 & Siswa 5 & 15 & 15 & 15 & 20 & 65 & & Tidak tuntas \\
6 & Siswa 6 & 15 & 15 & 15 & 15 & 60 & & Tidak tuntas \\
7 & Siswa 7 & 15 & 20 & 15 & 15 & 65 & & Tidak tuntas \\
8 & Siswa 8 & 15 & 20 & 15 & 15 & 65 & & Tidak tuntas \\
9 & Siswa 9 & 20 & 20 & 20 & 15 & 75 & Tuntas & \\
10 & Siswa 10 & 15 & 20 & 15 & 15 & 65 & & Tidak tuntas \\
11 & Siswa 11 & 15 & 20 & 15 & 15 & 65 & & Tidak tuntas \\
12 & Siswa 12 & 15 & 20 & 15 & 15 & 65 & & Tidak tuntas \\
13 & Siswa 13 & 15 & 15 & 15 & 15 & 60 & & Tidak tuntas \\
14 & Siswa 14 & 20 & 20 & 20 & 15 & 75 & Tuntas & \\
15 & Siswa 15 & 20 & 20 & 20 & 15 & 75 & Tuntas & \\
16 & Siswa 16 & 15 & 15 & 15 & 15 & 60 & & Tidak tuntas \\
17 & Siswa 17 & 15 & 15 & 15 & 15 & 60 & & Tidak tuntas \\
18 & Siswa 18 & 15 & 15 & 15 & 15 & 60 & & Tidak tuntas \\
19 & Siswa 19 & 15 & 20 & 15 & 15 & 65 & & Tidak tuntas \\
20 & Siswa 20 & 15 & 20 & 15 & 20 & 70 & Tuntas & \\
\hline Jumlah & 325 & 365 & 325 & 315 & 1330 & & \\
Ketercapaian & $56,77 \%$ & $87,55 \%$ & $56,77 \%$ & $47,91 \%$ & $66,50 \%$ & $30 \%$ & 70\% \\
\hline
\end{tabular}

Rumus:

$$
\text { Nilai }=\left(\frac{\text { skor perolehan }}{\text { skor maksimal }}\right) \quad x 100
$$

Keterangan analisis pencapaian indikator

A-1 = kesatuan gagasan dasar $\quad 20$

A-2 $=$ penggunaan struktur $\quad 30$

A-3 = pemilisan diksi 30

A-4 = tanda baca dan ejaan $\quad 20$

Berdasarkan hasil tes menulis paragraf dengan menerapkan metode inkuiri di atas diketahui bahwa jumlah rata-rata kelas 66,50, sementara hasil belajar siswa yang tuntas sebanyak 6 orang atau 30\% dan siswa yang tidak tuntas sebanyak 14 orang atau $70 \%$. Melihat permasalahan tersebut, peneliti masih perlu melakukan perbaikan selanjutnya untuk meningkatkan motivasi dan keinginan siswa mengikuti proses pembelajaran menulis paragraf. Karena dilihat dari hasil analisis ketercapaian indikator, siswa menentukan isi gagasan dasar 56,77\%, penggunaan struktur kaliamt yaitu $87,55 \%$, dan penulisan diksi $47,91 \%$, dan tanda baca dan ejaan 79,68\%. Maka, dengan demikian hasil ini perlu dilakukan tindakan pada siklus selanjutnya.

Dari hasil siklus I ini dapat dikatakan bahwa ketuntasan hasil menulis paragraf dengan menentukan ide pokok siswa SD Negeri 2 Laemanta masih berkategori 
kurang. Skor rata-rata hasil menulis paragraf belum mencapai skor ideal sebesar $75 \%$

\section{Tindakan Siklus II}

Pada table di bawah ini dapat dilihat gambaran tentang kemampuan melakukan pembelajaran menulis pada siklus II dari komponen yang diamati dalam pencapain indicator maka dari itu peneliti akan melakukan siklus II.

Tabel 3. Penilaian Menulis Paragraf Siklus II

\begin{tabular}{ccccccccc}
\hline No & Nama & A-1 & A-2 & A-3 & A-4 & Skor & \multicolumn{2}{c}{ Ketuntasan } \\
& & $\mathbf{2 0}$ & $\mathbf{3 0}$ & $\mathbf{3 0}$ & $\mathbf{2 0}$ & & & \\
\hline 1 & Siswa 1 & 20 & 20 & 20 & 20 & 80 & Tuntas & \\
2 & Siswa 2 & 15 & 15 & 15 & 20 & 65 & & Tidak tuntas \\
3 & Siswa 3 & 20 & 20 & 20 & 20 & 80 & Tuntas & \\
4 & Siswa 4 & 20 & 20 & 20 & 15 & 75 & Tuntas & \\
5 & Siswa 5 & 20 & 15 & 15 & 15 & 65 & & Tidak tuntas \\
6 & Siswa 6 & 20 & 25 & 20 & 20 & 85 & Tuntas & \\
7 & Siswa 7 & 20 & 30 & 30 & 20 & 100 & Tuntas & \\
8 & Siswa 8 & 20 & 20 & 20 & 20 & 80 & Tuntas & \\
9 & Siswa 9 & 20 & 20 & 20 & 15 & 75 & Tuntas & \\
10 & Siswa 10 & 20 & 20 & 20 & 20 & 80 & Tuntas & \\
11 & Siswa 11 & 20 & 20 & 20 & 20 & 80 & Tuntas & \\
12 & Siswa 12 & 20 & 20 & 20 & 20 & 80 & Tuntas & \\
13 & Siswa 13 & 20 & 25 & 20 & 20 & 80 & Tuntas & \\
14 & Siswa 14 & 20 & 20 & 20 & 15 & 75 & Tuntas & \\
15 & Siswa 15 & 20 & 20 & 20 & 15 & 75 & Tuntas & \\
16 & Siswa 16 & 20 & 25 & 20 & 20 & 85 & Tuntas & \\
17 & Siswa 17 & 20 & 25 & 20 & 20 & 85 & Tuntas & \\
18 & Siswa 18 & 20 & 15 & 15 & 15 & 65 & & Tidak tuntas \\
19 & Siswa 19 & 20 & 25 & 20 & 20 & 85 & Tuntas & \\
20 & Siswa 20 & 20 & 25 & 20 & 20 & 85 & Tuntas & \\
\hline \multicolumn{1}{c}{ Jumlah } & 415 & 455 & 425 & 385 & 1680 & & \\
Ketercapaian & $80 \%$ & $98,2 \%$ & $80,2 \%$ & $75 \%$ & $84 \%$ & $85 \%$ & $15 \%$ \\
\hline
\end{tabular}

Rumus:

Nilai $=\left(\frac{\text { skor perolehan }}{\text { skor maksimal }}\right) \quad x 100$

Keterangan analisis pencapaian indikator

A-1 = kesatuan gagasan dasar $\quad 20$

A-2 = penggunaan struktur $\quad 30$

A-3 = pemilisan diksi 30

A-4 = tanda baca dan ejaan 20

Sehubungan dengan data ketuntasan belajar hasil menulis paragraf dengan menerapkan metode inkuiri dibandingkan dengan siklus I, pada siklus II mengalami peningkatan yang signifikan, siswa yang tidak tuntas $15 \%$, dan siswa yang tuntas $85 \%$. Dengan dilihat dari hasil analisis ketercapaian indikator, siswa menentukan kesatuan gagasan $80 \%$, penggunaaan struktur $98,2 \%$, pemilihan diksi $80,2 \%$, dan penggunaan tanda baca $75 \%$. Dengan demikian ketuntasan hasil menulis paragraph dengan menerapkan metode inkuiri pada siklus II tidak perlu dilakukan tindakan selanjutnya.

Pembahasan pada penelitian tindakan kelas ini didasarkan pada hasil penelitian siklus I dan siklus II menggunakan model Kemmis dan Mc. Taggart . Hasil pada kedua siklus tersebut digunakan untuk mengetahui peningkatan kemampuan menulis paragraf dengan menerapkan metode inkuiri dan untuk mengetahui perubahan perilaku siswa selama melakukan proses pembelajaran. Penelitian ini menggunakan empat tahap dalam mengambil data baik data tes maupun data nontes yaitu tahap perencanaan, tahap pelaksanaan, tahap pengamatan, dan tahap refleksi. Dari analisis penelitian tindakan 
kelas diperoleh temuan-temuan didasarkan pada hasil uji keterampilan menulis paragraf dengan menerapkan metode inkuiri pada siklus pertama diuraikan sebagai berikut. (a) perencanaan, (b) pelaksanaan, (c) observasi, dan refleksi.

\section{SIKLUS I}

Pada pemebelajaran menulis paragraf dengan menerapkan metode inkuiri siswa SD Negeri 2 Laemanta, sesuai hasil observasi aktivitas siswa, diketahui siswa masih memperoleh nilai $18,75 \%$ dengan kategori kurang, dan hasil tes unjuk kerja kemampuan menulis paragraf dengan metode Inkuiri ketuntasan belajar secara klasikal 12,5\% yang berarti bahwa hasil belajar siswa belum memenuhi ketuntasan hasil belajar secara klasikal (kelas) minimal $75 \%$ dan hasil belajar secara individual minimal $70 \%$ sebagaimana yang telah ditepatkan sebelumnya. Hal ini menunjukan guru untuk melakukan perubahan-perubahan dalam meningkatkan kuatitas proses pembelajaran pada siklus berikutnya.

\section{SIKLUS II}

Siklus II menunjukan hasil belajar siswa sudah sangat baik dengan memperoleh angka rata-rata hasil evaluasi siklus II sebesar $85,62 \%$ dan ketuntasan hasil belajar secara klasikal 90,62\%. Hal itu, berarti bahwa secara klasikal proses belajar mengajar telah tuntas karena telah mencapai indikator ketuntasan hasil belajar, meskipun masih terdapat 3 orang siswa memperoleh nilai 65 dengan kategori cukup baik dan belum mencapai ketuntasan, Ketidaktuntasan siswa tersebut disebabkan oleh berbagai faktor, seperti ada siswa yang kurang sehat atau berhalangan sehingga tidak maksimal dalam pembelajaran berlangsung, kurang fokus menerima materi pelajaran, dan masih terdapat siswa yang tidak serius dalam menulis paragraf. Dengan latar belakang yang memang perlu perhatian khusus dari guru.

\begin{tabular}{ccccc}
\multicolumn{6}{l}{ Tabel } & Rekapitulasi Nilai Rata-Rata & \multicolumn{3}{c}{ Rasil Belajar Ketuntasan Siklus I dan II } \\
\hline No & Siklus & Nilai Rata-Rata & Tuntas & Tidak tuntas \\
1 & I & 66,50 & $30 \%$ & $70 \%$ \\
2 & II & 84 & $85 \%$ & $15 \%$ \\
\hline \multicolumn{2}{l}{ Peningkatan } & $55 \%$ & $55 \%$ & $15 \%$ \\
\hline
\end{tabular}

Mencermati hasil pencapaian pada table 4 di atas menunjukan bahwa hasil belajar ketermpilan menulis paragraph dengan menerapkan metode inkuiri dari siklus I dan II peneliti memperhatikan adanya peningkatan signifikan yaitu dari nilai rata rata hasil belajar siklus 1 sebesar 66,50 menjadi 84 pada siklus II atau naik 55\%, dengan melihat hal tersebur ketuntasan hasil belajar secara klasikal dari $30 \%$ siklus I meningkat menjadi $85 \%$ pada siklus II, atau mengalami peningkatan sebesar sebesar 55\%. Maka, hasil yang diperoleh tersebut telah memenuhi kriteria ketuntasan klasikal sebagaimana yang ditetapkan pada indicator penelitian minimal $80 \%$.

\section{KESIMPULAN}

Berdasarkan hasil penelitian menulis paragraf dengan menerapkan metode inkuiri siswa kelas IV SD Negeri 2 Laemanta dapat disimpulkan bahwa penerapan metode inkuiri dapat ditingkatkan. Berdasarkan hasil penelitian tes awal sampai tes akhir, terlihat signifikan pada kemapuan menulis paragraf dengan menerapkan metode inkuiri. yaitu dari nilai rata rata klasikal $56,75 \%$ pada pratindakan yang termasuk kategori sangat kurang, kemudian nilai rata rata siklus I sebesar 66,5 yang masuk kategori cukup baik, namun hasil tersebut belum memenuhi target yang sudah ditentukan yaitu secara klasikal KKM minimal 75. Sementara itu, nilai rata rata pada siklus II sebesar $84 \%$ yang masuk dalam kategori sangat baik. Dengan demikian, terjadi peningkatan hasil menulis paragraf sebesar $84 \%$ dari siklus I ke siklus II, denagn melihat tersebut ketuntasan hasil belajar secara klasikal dari 30\% pada siklus I meningkat menjadi $85 \%$ pada siklus II dengan mengalami peningkatan sebesar $85 \%$. Maka, hasil yang diperoleh tersebut telah memenuhi KKM, sebagaiman yang ditetapkan pada indikator penelitian ini secara individual minimal 70 dan ketuntasan klasikal (kelas) minimal 75 
SARAN

Berdasarkan hasil penelitian, pembahasan, dan simpulan, maka peneliti memberikan saran sebagai berikut: (1) sebagai bahan masukan bagi guru dalam proses melaksanakan pembelajaran Bahasa Indonesia untuk menggunakan metode inkuiri khususnya pada aspek keterampilan menulis paragraf agar pembelajaran menjadi lebih optimal sehingga hasil belajar siswa dapat meningkat. Selain itu, metode inkuiri dapat meningkatkan aktivitas dan motivasi belajar siswa, dan (2) pada proses pembelajaran hendaknya guru melibatkan siswa secara aktif agar siswa merasa lebih dihargai dan diperhatikan sehingga akan meningkatkan keterampilan belajar siswa dan hasil belajar siswa. optimal sehingga hasil belajar siswa dapat meningkat, dengan diterapkan metode inkuiri siswa diharapkan dapat memahami tentang menulis paragraf dengan baik karena metode inkuiri ini sangat sederhana dan membantu para siswa untuk mengepresikan berbagai pikiran, gagasan, pendapat dan perasaan.

\section{DAFTAR PUSTAKA}

Akhaidah, dkk. (2014). Kemampuan Menulis Bahasa Indonesia. Jakarta :Erlangga.

Hanafiah, suhana. (2010). Konsep Startegi Pembelajaran. Bandung :PT Refika Aditama.

Rochiati. (2012). Metode Penelitian Tindakan Kelas. Bandung : PT. Remaja Rosdakarya.

Rocmadi, dkk. (2014). Paragraf Pengembangan dan Implementasi. Jogjakarta : Media Pustaka.

Sanjaya, Wina. (2011). Strategi Pembelajaran Beroriantasi Standar Proses Pendidikan. Jakarta : Kencana.

Tarigan hendri Guntur (2008.) Menulis Sebagai Suatu Keterampilan Berbahasa. Bandung : Angkasa.

Wiyanto, Asul. (2014). Terampil Menulis Paragraf . Jakarta: Gasindo. 